\title{
SEROLOGICAL INVESTIGATIONS INTO THE CAUSE OF DEATH OF GOAT $\times$ SHEEP HYBRID FOETUSES
}

\author{
E. M. TUGKER, $*$ P. T. MaGOVERN $\dagger$ AND J. L. HANGOCK $\dagger$ \\ * ARC Institute of Animal Physiology, Babraham, Cambridge, and \\ $\uparrow$ Department of Anatomy, Royal Veterinary College, London NW1 0TU
}

(Received 19th February 1971)

\begin{abstract}
Summary. Experiments are described which were designed to examine the possibility that death of the goat $\times$ sheep hybrid foetus is due to the passage of haemolytic antibody from mother to foetus. 'Naturally occurring' haemolytic antibodies to sheep red cells were found in the sera of some goats with normal or hybrid pregnancies. 'Heterologous' antibodies, considered to be of the immune type, were found in some but not all goats with hybrid foetuses; these 'heterologous' antibodies were not found in goats carrying goat foetuses. No immune globulins of maternal or foetal origin were found in foetal plasma or in allantoic or amniotic fluids. No real evidence was obtained for the presence of immune globulins on the red cells of hybrids whether or not their mothers had anti-sheep haemolysins in their sera. It is concluded that haemolytic antibodies are not responsible for the death of the goatx sheep hybrid foetus.
\end{abstract}

The electrophoretic pattern of hybrid haemoglobin was examined.

\section{INTRODUCTION}

Numerous attempts have been made to cross-breed domestic sheep and goats, and although the conception rate in goats inseminated with sheep semen is high, there is ample evidence that the hybrid foetus fails to survive beyond the 2nd month of gestation (Warwick, Berry \& Horlacher, 1932, 1933, 1934, 1935; Quinlan, Roux, van Aswegan \& de Lange, 1941; Hancock, 1964). Alexander, Williams \& Bailey (1967) concluded that the death of the hybrid foetus is the result of a destruction of its red blood cells by haemolytic antibodies which appear in the sera of goats during hybrid pregnancy. The suggestion made was that passage of haemolytic antibodies to the foetus is facilitated by certain abnormalities of placental structure. Normally, the placentae of goats and sheep are impermeable to maternal antibodies and, in both species, passive transfer of immunity to the offspring is entirely by way of the colostrum (Brambell, Hemmings \& Henderson, 1951). No direct evidence of transplacental passage of antibodies was given in the report by Alexander et al. (1967).

The experiments described here were designed to see if antibodies can be detected in the hybrid foetal plasma or on the surface of the hybrid foetal red blood cells and to obtain information on the time in pregnancy at which 
antibodies appear. Examinations were also made of the haemoglobins in goat and hybrid foetuses.

The sheep R-O and the goat J-O blood group systems are similar and the so-called 'naturally-occurring' antibodies, which characterize these systems, cross react to a certain extent (Tucker, 1962). It was considered important in this study to distinguish such antibodies (i.e. 'naturally-occurring' ones) from those of immune type which might appear as a direct result of stimulation by sheep antigen (i.e. 'heterologous' or anti-sheep antibodies). For this reason, where possible, the sheep and goats were tested for their $\mathrm{R}(\mathrm{J})-\mathrm{O}$ groupings and, in addition, the specificity of the antibodies detected in the sera of the pregnant goats was determined to decide if they were of the 'naturally-occurring' or 'heterologous' type.

Sheep and goat antibodies do not normally agglutinate sheep or goat red cells directly, and their presence can only be detected by such means as a haemolytic or an antiglobulin test. The haemolytic test is the method usually employed in sheep and goat blood group studies and depends on the fact that red cells which are sensitized by specific antibody are haemolysed in the presence of complement. This is the test which has been mostly used in the present investigation. In addition, foetal red cells were tested for the presence of antibody by means of the antiglobulin test. The basis of this method is that red cells which have antibody, i.e. immune globulin (IgG) on their surface, are agglutinated when treated with a serum (often rabbit serum) containing antibody to this globulin (see Mollison, 1967a).

\section{MATERIALS AND METHODS}

The animals used were female goats of mixed breeding. Except where stated, the goats had received no previous experimental treatment and had not carried hybrids previously. The goats were either mated naturally by male goats or inseminated artificially with fresh, undiluted sheep semen collected from Scottish Blackface rams.

In a preliminary experiment (Exp. 1), the levels of haemolytic antibodies were determined in samples of serum obtained at varying intervals during eight hybrid and eight normal pregnancies from goats involved in other experiments. Sera were also examined from four goats carrying sheep foetuses following egg transfer (see Hancock \& McGovern, 1968).

In the main experiment (Exp. 2), the males and females used were of previously determined blood types. Samples of blood were obtained at weekly intervals from nine goats carrying hybrid foetuses and from six goats carrying goat foetuses, beginning 3 weeks before insemination or mating and continuing up to the time of autopsy. The sera were stored at $-20^{\circ} \mathrm{C}$ before titration.

Seven goats with hybrid foetuses and five goats with goat foetuses were examined at autopsy at 35 to 43 days' gestation to obtain living embryos as close as possible to the time of death. The choice of time was based on previous observations on the survival of hybrid foetuses (see Hancock, McGovern \& Stamp, 1968).

The goats were killed by intravenous injection of pentobarbitone sodium 
(Euthatal; May and Baker Ltd). At autopsy, blood samples were obtained from the foetuses by cardiac puncture with a Pasteur pipette, and temporarily stored in heparinized capillary tubes. Foetal red blood cells were also obtained from saline washings of extravasated blood. These were transferred to heparinized disposable plastic bottles. Samples of allantoic and amniotic fluids were also obtained. Care was taken to avoid contamination with maternal blood and the foetuses were rinsed in saline before sampling.

At Day 25 of gestation, four goats carrying hybrid foetuses were each given one 14-ml injection of an emulsion of equal parts of sheep whole blood and Freund's complete adjuvant (Difco Laboratories). For each goat, the blood was obtained from the ram used for her insemination. The animals were examined at autopsy on Days 35 to 37 of gestation; samples of foetal blood and of amniotic and allantoic fluids were obtained as described earlier.

\section{Serological methods}

The haemolytic test was a simple three-drop test, with $2 \%$ red cell suspension, antiserum and complement (Tucker, 1965). The test was incubated at $32^{\circ} \mathrm{G}$ for $2 \mathrm{hr}$ and then read after a further $2 \mathrm{hr}$ at room temperature. Complement was prepared from pooled rabbit or guinea-pig sera, previously absorbed in the cold with sheep and goat red cells. It was stored at $-70^{\circ} \mathrm{G}$ until just before use.

Red cells from the parent sheep and goats were tested in a haemolytic test with specific sheep anti-R $(\mathrm{J})$ and anti-O blood-typing reagents (Tucker, 1962). Sheep red cells lysed by anti-R were of Group $R$, those lysed by anti-O were Group $\mathrm{O}$ and those not lysed by either reagent were Group i. Goat red cells were either J-positive, i.e. lysed by anti-R, or J-negative, i.e. not lysed by anti-R. The anti-O reagent does not haemolyse J-negative goat red cells, therefore these goats could not be further subdivided into $\mathrm{O}$-positive or $\mathrm{O}$ negative groupings.

To determine the strength of the haemolysins in sera of pregnant goats, 'doubling-up' dilutions from 1 in 2 to 1 in 1024 of the sera were made and tested in a haemolytic test against Groups $\mathrm{R}$ and $\mathrm{O}$ sheep red cells. The degree of haemolysis in each tube was recorded as 1 to 5, 5 being complete haemolysis. The antibody score was obtained by adding up the degree of haemolysis recorded for each dilution. To determine the specificity of the haemolysins (i.c. whether 'natural' or 'heterologous'), undiluted sera from the pregnant goats were tested in a haemolytic test against a panel of red cells from nine Group $\mathrm{R}$, four Group $\mathrm{O}$ and one Group i sheep. If the sera only haemolysed Group $\mathrm{R}$ or Group $\mathrm{O}$ red cells, but not Group i, they were considered to be of the 'naturally-occurring' type, i.e. anti-R or anti-O. If they haemolysed all sheep red cells in the panel, they were considered to be more probably of the heterologous variety, i.e. directed against species-specific antigens. This arbitrary classification was the basis on which the antibodies were described as 'naturally-occurring' or 'heterologous type' in this paper. Since normal goat sera do not usually haemolyse all classes of sheep red cells in the normal haemolytic test, such heterologous antibodies can be considered likely to be the direct result of stimulation by sheep antigen. The direct antiglobulin test was 
done on an opal tile according to the standard procedure (Mollison, 1967a). Two different antiglobulin sera (D 41 and anti-Fab) were used. Antiserum D 41 was made in a rabbit against goat serum; anti-Fab was an antiserum raised in a rabbit against isolated sheep IgG Fab fragment. The antiglobulin sera were absorbed with pooled sheep and goat red cells before use, and were used at dilutions ranging from 1 in 4 to 1 in 80 . Antiserum D 41 normally worked effectively against sensitized sheep red cells at a dilution up to 1 in 640 , and anti-Fab was effective at dilutions up to 1 in 40 .

The foetal haemoglobins were separated by horizontal starch gel electrophoresis in a continuous tris-EDTA-borate buffer system at $\mathrm{pH} 8.9$ (Gahne, Rendel \& Venge, 1960). Immunoelectrophoresis of foetal plasma and of allantoic and amniotic fluids was carried out in barbitone buffer, $\mathrm{pH} 8.6$ (Hirschfeld, 1960).

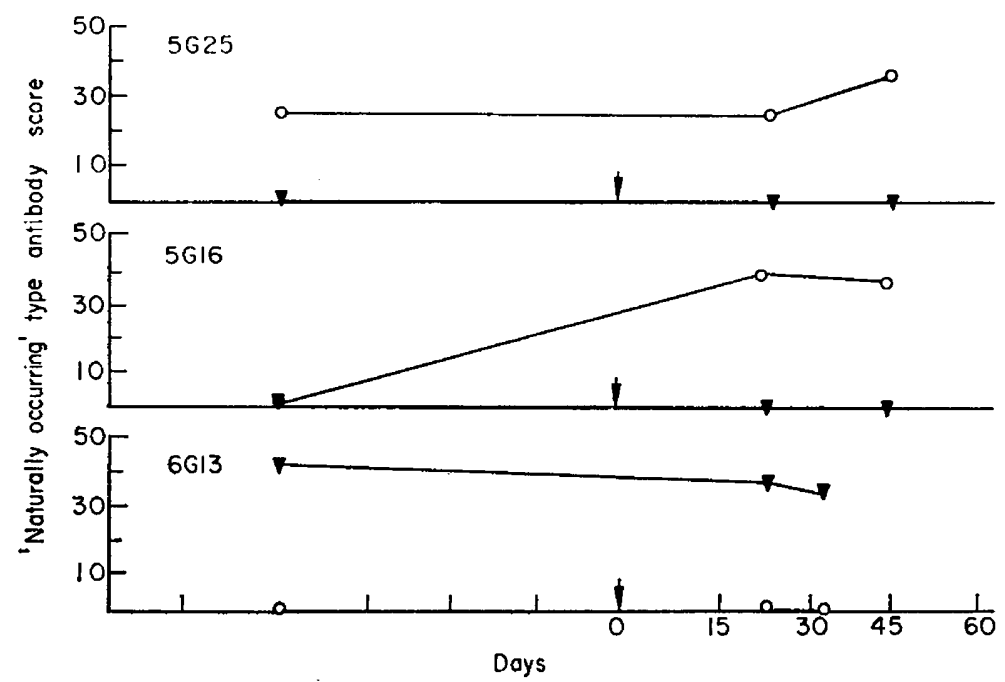

TEXT-FIG. 1. The levels and the specificity of serum antibody in goats carrying normal foetuses (Exp. 1). $\downarrow$, Time of insemination; 0 , lysis of Group O sheep red cells; $\nabla$, lysis of Group $R$ sheep red cells.

\section{RESULTS}

\section{Preliminary observations (Experiment 1)}

Antibodies of the 'heterologous' anti-sheep type were found in none of eight goats carrying goat foetuses but 'naturally-occurring' antibodies were detected in sera of three of these goats, 5G25, 5G16, 6G13 (Text-fig. 1); in two of these, there were high levels of anti-O antibodies and in the third, there were high levels of anti-R antibodies. The level of antibodies in two of the three animals did not appear to have altered as the result of pregnancy.

Antibodies were identified in the sera of five of eight goats carrying hybrid foetuses (5G3, 6G41, 5G46, 5G14, 4G6). Some of these animals (Text-fig. 2) had received, for reasons unconnected with this experiment, intravenous injections of sheep semen at weekly intervals for 21 weeks before insemination. 'Naturally-occurring' anti-O and anti- $\mathrm{R}$ antibodies were detected in one 
semen-treated goat (5G3). Antibodies which reacted against the whole panel of sheep red blood cells, i.e. antibodies of the 'heterologous' type, were detected in the sera of two semen-treated (6G41, 5G46) and in two untreated goats (5G14, 4G6). Because these animals were sampled so infrequently, it is not possible to say exactly when the 'heterologous' anti-sheep antibodies made their appearance. In three goats, negative results at Days 32 (6G41), 36 (5G14) and 53 (5G46) were followed by positive results at Days 48,52 and 71, respectively.

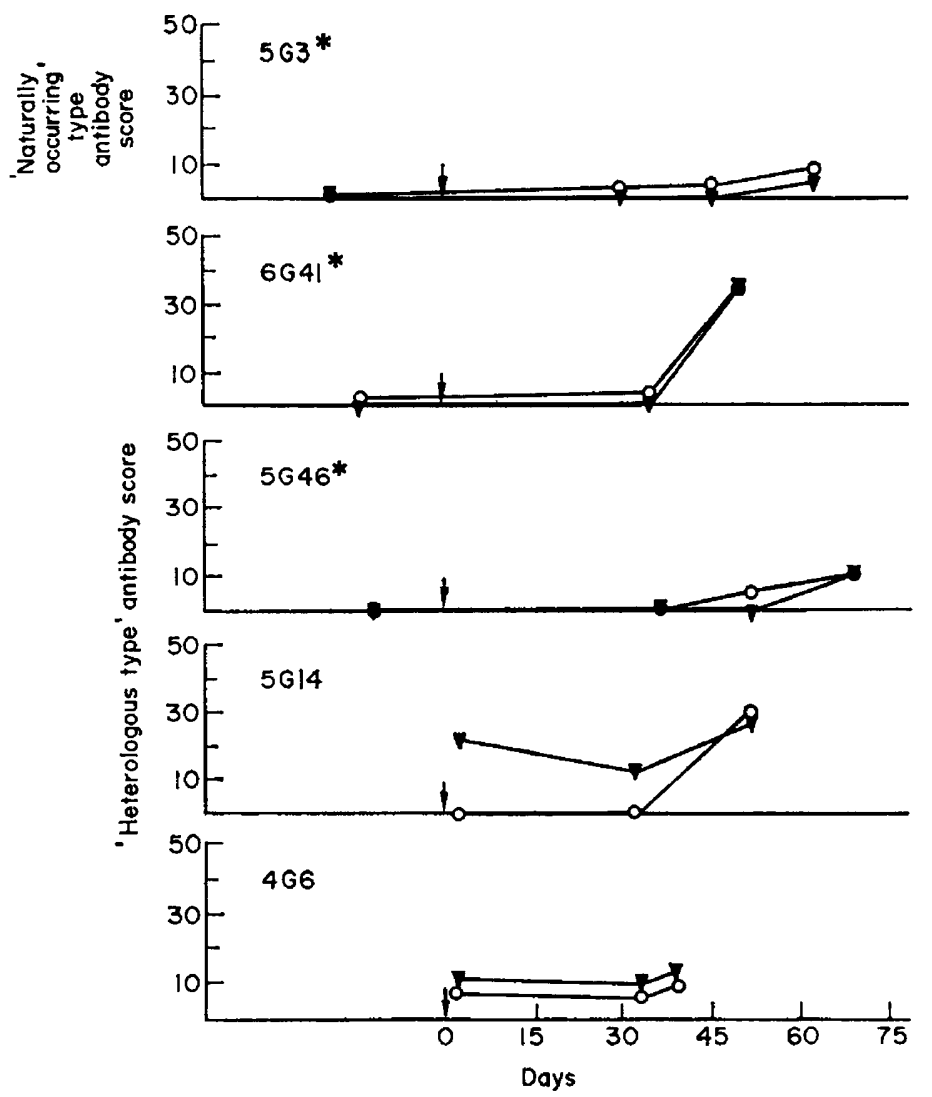

TEXT-FIG. 2. The levels and the specificity of serum antibody in pregnant goats carrying hybrid foetuses (Exp. 1). $\downarrow$, Time of insemination; $O$, lysis of Group O sheep red cells; $\nabla$, lysis of Group $R$ sheep red cells.

* Goats which received semen injections.

The fourth goat (4G6) had 'heterologous' type antibodies in the serum at the beginning of gestation and there was apparently no change in their level. In this goat, there was no history of a previous hybrid pregnancy although the goat had been inseminated with sheep semen during the previous season but had apparently not conceived. When examined at autopsy on Day 38 of gestation, this animal contained a dead hybrid foetus which, judged by its length $(20 \mathrm{~mm})$, appeared to have died earlier in gestation than is usual.

'Heterologous' anti-sheep antibodies appeared in the sera of only one of the 
four goats carrying sheep foetuses. Anti-O antibodies appeared in one goat and increased in titre in another. No changes were detected in the remaining goat.

Main experiment (Experiment 2)

In this experiment, the animals used were of known blood type, and samples were taken from the pregnant goats at more frequent intervals than was the case in Exp. 1.

Of six control goats (five J-negative and one J-positive) carrying goat foetuses, no antibodies were detected in five but in the remaining $\mathrm{J}$-negative goat (M94), antibodies did appear during the 3rd week of gestation (Text-fig. 3a).
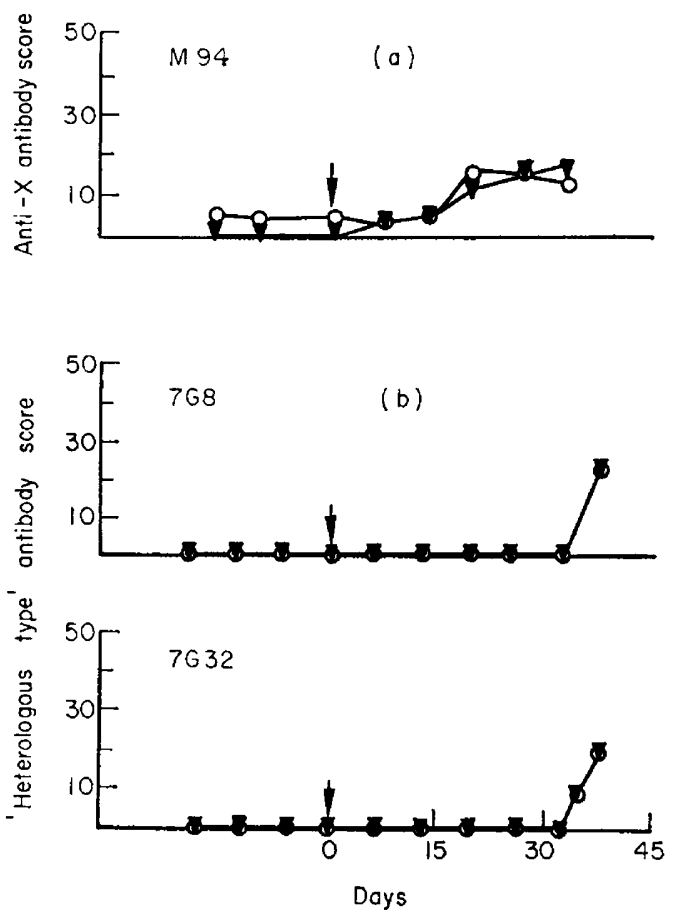

TEXT-Fig. 3. The levels and the specificity of serum antibody (Exp. 2) in: (a) pregnant goat carrying a normal foetus; (b) pregnant goats carrying hybrid foetuses. $\downarrow$, Time of insemination; $O$, lysis of Group O sheep red cells; $\nabla$, lysis of Group $R$ sheep red cells.

The antibody referred to as anti-X, was not the 'naturally occurring' anti-O or anti-R antibody nor was it a typical antibody of the 'heterologous' type in that it reacted with only some and not all of the sheep red blood cells in the test panel.

Sera were examined from nine goats carrying hybrid embryos. Both of the rams used for insemination were O-positive. Seven of the pregnant goats, of which four were J-positive and three J-negative, had no detectable antibodies in the sera up to the time of autopsy. In the remaining two J-negative goats (7G8 and 7G32), 'heterologous' anti-sheep antibodies were detected in the sera at Days 35 and 36 (Text-fig. $3 \mathrm{~b}$ ). 
Samples of foetal red cells, foetal serum and amniotic and allantoic fluids were obtained at autopsy from seven of the nine goats. Six of the goats carrying hybrid foetuses, in which no haemolytic antibodies were detected, were examined at autopsy. Four yielded six live foetuses at autopsy between Day 35 and Day 38; two dead foetuses were recovered from the others at autopsy on Day 39. One of the two goats (7G32) in which antibodies were detected was examined at autopsy on Day 42 and yielded two dead foetuses.

Ten goat foetuses were recovered from five goats examined at Days 35, 38, 38,39 and 43 of gestation.

The foetal plasma and amniotic and allantoic fluids were examined by immunoelectrophoresis for evidence of immune globulins of either maternal or foetal origin. No IgG precipitation lines were found in any of the goat or hybrid foetal samples tested, including those of the two dead hybrid foetuses from one of the goats which had haemolytic antibodies in the serum at the time of autopsy. Plate 1, Fig. 1 compares the typical precipitation lines obtained for the plasma of a hybrid and normal goat foetus and an adult goat and sheep.

The direct antiglobulin tests for the presence of immune globulins on the foetal red cells were carried out using two different antiglobulin sera. The red cells from the goat foetuses were regularly agglutinated by a dilution of 1 in 10 , and sometimes of 1 in 20 to 1 in 40, of D 41 antiglobulin (rabbit anti-goat serum), whereas the hybrid cells gave a more variable result, being often agglutinated at a dilution of 1 in 20 to 1 in 40, and in one case by a dilution of 1 in 80 , of D 41 serum. Since this antiglobulin normally works well at a dilution of 1 in 640, it was concluded that this agglutination was probably due to the presence of other proteins, such as transferrins, on the red cell surface (Mollison, 1967b). This conclusion was supported by the fact that none of the red cell samples was agglutinated by the specific anti-Fab antiglobulin reagent.

Direct treatment of the goat and hybrid foetal red cells with either guinea-pig or rabbit complement invariably gave a clear negative result. In addition, treatment of the cells with maternal serum (taken at the time of autopsy) plus complement also failed to bring about haemolysis.

The hybrid foetuses tested in the above experiments were derived from mothers who, with one exception, had no detectable antibodies in their sera. For this reason, four goats were immunized by injection of blood from the ram which had been used to inseminate them. At the time of autopsy, all four goats were found to have anti-sheep haemolytic antibodies (antibody score greater than 60 , i.e. a titre of over 1 in 2000). Four live hybrid foetuses were recovered from three of the goats at Days 35, 36 and 37 and two dead foetuses were recovered from the fourth goat at Day 36 . Only haemolysed blood samples were obtained from each of the two dead foetuses and could not be tested, but the intact red cells of the live foetuses were tested in the usual way. All samples remained unhaemolysed when treated directly with guinea-pig and rabbit complement. When treated with freshly collected serum from the immunized mothers, they haemolysed within a few minutes, even before the addition of complement, thus confirming that sheep antigens were present on the red cells. The failure of complement alone to induce haemolysis is evidence that maternal antibody failed to reach the red cells. Three of the samples gave 
a negative anti-globulin test with anti-Fab; the red cells of one of the hybrids were agglutinated up to a dilution of 1 in 40 of the anti-Fab. The reason for the latter result is unknown.

Immunoelectrophoresis revealed no IgG lines in any of these foetal plasma samples and the result with the haemolysed blood from the two dead foetuses was also negative.

Plate 1, Fig. 2 shows the electrophoretic pattern of the haemoglobins of the hybrid and goat foetus. The goat foetal haemoglobin comprised two bands, a strong fast-migrating band and a weaker, slower band. The hybrid haemoglobin had these two bands, together with one in the position consistent with that of sheep foetal haemoglobin, which has a mobility, at this $\mathrm{pH}$, faster than that of sheep haemoglobin B.

\section{DISCUSSION}

The results clearly fail to provide any real evidence that death of goat $\times$ sheep hybrid foetuses is the result of a destruction of their red blood cells by antibodies of maternal origin. On the contrary, there is evidence that hybrid foetuses are able to survive for a while despite the existence of very high titres of maternal haemolysins produced experimentally. Moreover, death of the hybrid occurred in two goats in which haemolytic antibodies were undetected.

Care was taken to distinguish between antibodies of the heterologous type and the 'naturally-occurring' anti-O and anti-R antibodies which are known to show seasonal fluctuations in strength. The 'naturally-occurring' antibodies are not likely to cause haemolysis of foetal cells since $O$ and $R$ antigens cannot be detected on the surface of sheep red blood cells until sometime after birth (Rendel, 1957).

The finding that relatively small numbers of goats developed immune antibodies during hybrid pregnancy contrasts with that recorded by Alexander $e t$ al. (1967) who were able to detect antibodies in the sera of all thirteen goats carrying hybrid foetuses, although in a later series of experiments (Alexander \& Williams, 1968) antibodies were not detectable during hybrid pregnancy in two goats. The large number of negative results obtained in our main experiment may be attributed to failure to sample after the end of the 6 th week of gestation. The time at which the haemolysins appear in relation to hybrid death was not established but it is possible that in a number of cases the antibodies do not appear until after the foetus has died. Indeed, in the report by Alexander et al. (1967), clear evidence that the appearance of antibodies preceded the death of the embryo was obtained in only two of seven goats examined. It is likely, therefore, that the haemolytic antibodies are not, themselves, directly involved in terminating hybrid pregnancy but are a sequel to a reaction on a broader immunological front than that postulated by the Australian workers.

The finding that the electrophoretic pattern of the hybrid haemoglobin consisted of three bands was in agreement with that of Bailey, Alexander \& Williams (1967). These workers were puzzled by the existence of the slowest band which they failed to detect in a normal goat foetal haemoglobin. Our 
PLATE 1

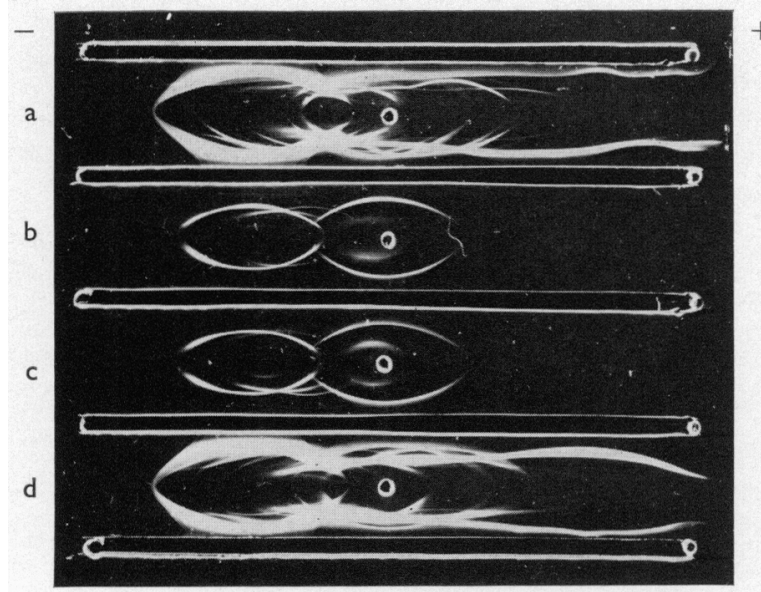

Fig. 1. Immunoelectrophoresis of plasma samples. $a=$ adult goat, $b=$ goat foetus, $\mathrm{c}=$ hybrid foetus, $\mathrm{d}=$ adult sheep. Rabbit anti-sheep and rabbit anti-goat sera placed in alternate grooves. Note the absence of IgG from foetal plasma.

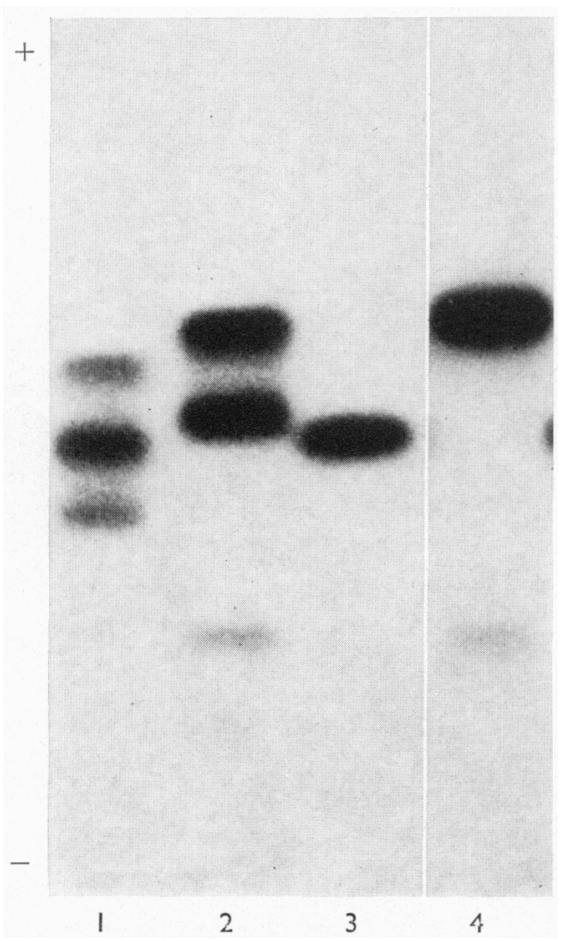

FIG. 2. Electrophoretic separation of haemoglobins. Starch gel electrophoresis $\mathrm{pH} 8 \cdot 9$. $1=$ sheep A B C $\mathrm{Hb}, 2=$ hybrid foetus $\mathrm{Hb}, 3=$ sheep B Hb, $4=$ goat foetus $\mathrm{Hb}$. 
results clearly show that this band is present in the haemoglobin of normal goat foetuses and therefore the hybrid haemoglobin pattern is according to expectation.

\section{ACKNOWLEDGMENTS}

This work was supported by a grant from the Agricultural Research Council to one of us (J.L.H.). We are grateful to Dr M. J. Hobart for providing the anti-Fab antiglobulin serum.

\section{REFERENCES}

Alexander, G. \& Williams, D. (1968) Failure of sheep $\times$ goat hybrid foetuses to survive in goats treated with sheep's blood. Aust. F. biol. Sci. 21, 953.

Alexander, G., Wildiams, D. \& Bailey, L. (1967) Natural immunization in pregnant goats against red blood cells of their sheep $\times$ goat hybrid foetuses. Aust. F. biol. Sci. 20, 1217.

Bailey, L. F., Alexander, G. \& Williams, D. (1967) The haemoglobins of a sheep-goat hybrid foetus and those of the parent species. Aust. J. biol. Sci. 20, 953.

Brambell, F. W. R., Hemmings, W. A. \& Henderson, M. (1951) Antibodies and embryos. Athlone Press, London.

GAHNe, B., ReNDEL, J. \& VENGE, O. (1960) Inheritance of $\beta$-globulins in serum and milk from cattle. Nature, Lond. 186, 907.

Hancock, J. L. (1964) Attempted hybridization of sheep and goats. 5th Int. Congr. Anim. Reprod. A.I., Trento, 3, 445.

Hancock, J. L. \& McGovern, P. T. (1968) Transfer of goat $\times$ sheep hybrid eggs to sheep and reciprocal transfer of eggs between sheep and goats. Res. vet. Sci. 9, 411.

Hancock, J. L., McGovern, P. T. \& Stamp, J. T. (1968) Failure of gestation of goat $\times$ sheep hybrids in goats and sheep. . Reprod. Fert. Suppl. 3, 29.

HirsCHFELD, J. (1960) Immunoelectrophoresis-procedure and application to the study of groupspecific variations in sera. Sci. Tools, 7, 18.

Mollison, P. L. (1967a) Blood transfusion in clinical medicine, 4th edn, p. 436. Blackwell Scientific Publications, Oxford.

Mollison, P. L. (1967b) Blood transfusion in clinical medicine, 4th edn, pp. 444-445. Blackwell Scientific Publications, Oxford.

Quintan, J., Roux, L. L., van Aswegen, W. G. \& de Lange, N. (1941) A note on the results of an attempt to fertilise native goat-ewes with sheep-rams. Onderstepoort 7. vet. Sci. Anim. Ind. 17, 115.

RENDEL, J. (1957) Further studies on some antigenic characters of sheep blood determined by epistatic action of genes. Acta agric. scand. 7, 224.

Tucrer, E. M. (1962) The soluble blood group substances in sheep and goats. Vox Sang. 7, 239.

TuCKer, E. M. (1965) Further observations on the i blood group in sheep. Vox Sang. 10, 195.

Warwigk, B. L., Berry, R. O. \& Horlacher, W. R. (1932) Cytological and hybridization studies with sheep and goats. Rep. Tex. agric. Exp. Stn, p. 24.

Warwick, B. L., Berry, R. O. \& Horlacher, W. R. (1933) Cytological and hybridization studies with sheep and goats. Rep. Tex. agric. Exp. Stn, p. 29.

Warwick, B. L., Berry, R. O. \& Horlacher, W. R. (1934) Cytological and hybridization studies with sheep and goats. Rep. Tex. agric. Exp. Stn, p. 30.

Warwick, B. L., Berry, R. O. \& Horlacher, W. R. (1935) Results of mating rams to Angora female goats. Rec. Proc. Am. Soc. Anim. Prod. 27th Annual Meeting. 1934, p. 225. 